\title{
THE DESCRIPTION OF STUDENTS' METACOGNITION IN MATHEMATICS PROBLEM SOLVING BASED ON PARENTS' PARENTING PATTERNS
}

\author{
Erni Basri $^{1)}$ \\ ${ }^{1}$ Prodi Pendidikan Matematika PPs UNM, Makassar, Indonesia \\ e-mail: erni.basri.eb@gmail.com
}

\begin{abstract}
The research aims to describe students' metacognition in mathematics problem solving based on parents' parenting patterns. The subjects who were described in the research consisted of 4 students with each had parenting pattern of authoritative type, authoritarian type, permissive type, and rejecting/neglecting type. The data were collected by giving one problem solving test and interview. To review the credibility of the data, it was conducted source and time triangulation. The conclusion based on the results of the test and interview are: (1) Metacognition skills of the subject with parents' parenting pattern of authoritative type are planning, predicting, monitoring, and evaluating skills; (2) Metacognition skills of the subjects with parents' parenting pattern of authoritarian type and permissive type are planning, predicting, and monitoring skills; (3) Metacognition skills of the subject with parents' parenting pattern of permissive type are planning and predicting skills.
\end{abstract}

Keywords: metacognition, problem solving, parents' parenting pattern

\section{PENDAHULUAN}

Prestasi akademik yang diraih siswa utamanya di jenjang Sekolah Menengah Atas (SMA), tentunya tidak terlepas pada kemampuan siswa dalam menguasai materi pengetahuan dan keterampilan yang diajarkan di sekolah. Mardjohan (Ellena \& Leonardi) mendefinisikan bahwa prestasi akademik sebagai indikator kunci yang menunjukkan penguasaan siswa terhadap materi pengetahuan dan keterampilan yang diajarkan di sekolah. Adanya penguasaan siswa terhadap pengetahuan dan keterampilan yang telah diajarkan, tergantung bagaimana usaha yang dilakukan siswa sendiri dalam memahami materi pelajaran. Dengan kata lain siswa mampu mengatur strategi belajar yang baik. Terkait dengan hal tersebut, Arsyad (2016: 4) mengemukakan bahwa salah satu komponen kognitif yang sangat erat kaitannya dengan usaha dan aktivitas siswa dalam menangkap dan memahami materi pelajaran yang diajarkan adalah strategi belajar (strategi kognitif). Penggunaan strategi kognitif dalam belajar, Arsyad (2016: 14) memandang dari dua hal yaitu: (a) penggunaan strategi kognitif yang sudah dilatihkan untuk memahami materi dan pemecahan masalah matematika yang dipelajari, dan (b) penggunaan strategi kognitif yang sudah dilatihkan pada proses belajar yang berbeda setelah beberapa waktu berselang.

Penggunaan strategi kognitif yang sudah dilatihkan untuk memahami materi dan pemecahan masalah disebabkan oleh kesadaran siswa berpikir tentang proses berpikirnya (kognisinya) sehingga mampu untuk mengontrol aktivitas kognisi seseorang dalam memecahkan masalah. Kesadaran siswa berpikir tentang proses berpikirnya sendiri, dikenal sebagai istilah metakognisi. Dan fungsi 
metakognisi sendiri adalah untuk mengatur aktivitas kognisi seseorang dalam memecahkan masalah.

Menurut Arsyad (2016: 38) bahwa wujud dari berpikir dalam pengertian metakognisi adalah apa yang seseorang ketahui (pengetahuan metakognitif), apa yang dilakukan seseorang (keterampilan metakognitif), dan bagaimana keadaan kognitif dan afektif seseorang (pengalaman metakognitif). Dalam penelitian Kartika, dkk (2015) pula menunjukkan subjek belum memiliki keterampilan metakognisi yang baik karena kurangnya kesadaran diri dalam proses berpikir sehingga belum bisa mengukur sejauh mana kekurangan dan kelebihan atau kemampuannya dalam memecahkan suatu masalah, sebaliknya siswa yang terampil dalam metakognisi, dapat mengetahui dan menyadari kekurangan maupun kelebihan diri mereka sendiri.

Adapun kaitan metakognisi dalam pemecahan masalah matematika, salah satunya ditunjukkan melalui pemikiran Polya (Anggo, 2011) yang menyebutkan sebagai "berpikir tentang proses" (thinking about the process) dalam kaitannya dengan kesuksesan pemecahan masalah. Bila dicermati langkah-langkah pemecahan masalah yang dikembangkan oleh Polya, tampak bahwa pemecahan masalah dilaksanakan berdasarkan pada adanya pengetahuan tentang kognisi (knowledge about cognition), serta pengaturan kognisi (regulation of cognition). Langkah-langkah pemecahan masalah yang dikemukakan Polya telah menjadi dasar bagi pengembangan strategi metakognitif, dan telah banyak dirujuk oleh para peneliti pendidikan, khususnya pendidikan matematika.

Selain itu, Desoete (2008) pun menyatakan bahwa metakognisi mempunyai dua komponen pada pemecahan masalah matematika yaitu 1) pengetahuan metakognisi dan, 2) keterampilan metakognisi. Desoete menggambarkan keterampilan metakognisi sebagai kemampuan yang dimiliki seseorang untuk mengendalikan keterampilan kognitifnya sendiri. Desoete menyatakan ada empat komponen dalam keterampilan metakognisi,yaitu:

a. Orientation or prospective prediction skills guarantee working slowly when exercises are new or complex and working fast with easy or familiar tasks.

b. Planning skills make children thank in advance of how, when and why to act in order to obtain their purpose through a sequence of sub goals leading to the main problem goal.

c. Monitoring skills are the on-line, self regulated control of used cognitive strategies through concurrent verbalization during the actual performance, in order to identify problem and modify plans.

d. Evaluations skill can be define as the retrospective (or off-line) verbalization after the event has transpired, where children look at what strategies where used and whether or not they led to a desired result.

Untuk melibatkan keterampilan metakognisi dalam memecahkan masalah, membutuhkan strategi pengembangan metakognitif. Oleh karena metakognisi seseorang tidak muncul begitu saja, namun membutuhkan pembiasaan untuk mengembangkan metakognitif berupa strategi. Selain itu, penelitian Flavel dalam Desmita (2006: 138) menyatakan tentang metakognitif lebih difokuskan pada anak-anak. Flavel menunjukkan bahwa anak-anak yang masih kecil telah menyadari adanya pikiran, memiliki keterkaitan dengan dunia fisik, terpisah 
dengan dunia fisik, dapat menggambarkan objek-objek dan peristiwa-peristiwa secara akurat atau tidak akurat, dan secara aktif menginterpretasikan tentang realitas dan emosi, serta dapat membedakan pikiran dengan pengetahuan. Berdasarkan hal tersebut, berarti kemampuan metakognitif telah berkembang sejak masa anak-anak awal dan terus berlanjut sampai usia sekolah.

Suherman (2001: 96) menyatakan bahwa perkembangan metakognitif dapat diupayakan melalui cara dimana anak dituntut untuk mengobservasi tentang apa yang mereka ketahui dan kerjakan, sangat penting bagi guru dan pendidik utamanya juga bagi orangtua untuk mengembangkan kemampuan metakognitif baik melalui pembelajaran ataupun mengembangkan kebiasaan di rumah. Oleh karena itu, peran orang tua juga sangat mendukung dalam hal mengembangkan metakognisi anak.

Mengingat bahwa orangtua merupakan area terdekat pada anak. Sehingga setiap gaya pengasuhan orangtua sangat dipengaruhi oleh kualitas interaksi antara anak dengan orangtuanya yang akan memberikan dampak yang berbeda pada anak, bagaimana anak terbentuk tentunya didapat dari pembiasaan-pembiasaan yang terjadi pada situasi rumah. Hal inilah yang terkadang mendasari anak untuk mengembangkan dirinya (Rita, dkk, 2008: 15). Setiap gaya pengasuhan atau tipe pola asuh orangtua terhadap anaknya akan memberikan suasana rumah yang berbeda. Apabila suasana emosional di dalam rumah yang terjadi, maka sangat membantu merangsang perkembangan otak anak yang sedang tumbuh dan mengembangkan kemampuan mentalnya. Sebaliknya, suasana tersebut bisa memperlambat perkembangan otak.

Beck (1992: 50) mengungkapkan bahwa banyak proyek riset jangka lama menunjukkan bahwa intelegensi anak akan berkembang ke tingkat yang lebih tinggi, bila sikap di rumah terhadap anak, hangat dan demokratis daripada dingin dan otoritas. Adanya perkembangan intelegensi anak melalui didikan atau gaya pengasuhan orangtua tentunya memberikan pengaruh pada perkembangan metakognitif anak.

Penanganan gaya pengasuhan orang tua yang berbeda-beda terhadap anaknya terletak pada setiap tipe pola asuh yang diterapkan orangtua terhadap anak. Terkait tipe pola asuh orang tua, Baumrind (1991: 62) membagi empat tipe pola asuh orang tua yaitu rejecting-neglecting, permissive, authoritarian dan autoritative. Baumrind (dalam Agustiawati, 2014: 30) menjelaskan karakter siswa mengenai pola asuh orang tua tipe demokratis bahwa anak dalam keluarga yang bersifat demokratis akan mempunyai tanggung jawab yang besar terutama dalam menyelesaikan tugas-tugas pelajaran di sekolah, mampu berinisiatif dan kreatif serta mempunyai konsep diri yang positif. Sedangkan pola asuh orang tua bersifat otoriter dilihat dari profil perilaku anak, maka anak akan terhambat daya kreatifitas dan keberanian untuk mengambil keputusan/berinisiatif, tidak mencetuskan ide-ide. Sehingga hal itu akan berpengaruh kurang baik terhadap perkembangan metakognisi anak. 
Dengan melihat uraian diatas, maka menarik apabila diteliti secara khusus mengenai metakognisi siswa dalam pemecahan masalah matematika ditinjau dari pola asuh orang tua.

\section{METODE PENELITIAN}

Jenis Penelitian

Penelitian ini adalah penelitian deskriptif dengan pendekatan kualitatif yang bertujuan untuk mendeskripsikan metakognisi siswa dalam pemecahan masalah matematika ditinjau dari pola asuh orang tua.

\section{Subjek Penelitian}

Penelitian ini dilakukan pada siswa kelas X MIA 5 dan X MIA 6 MAN 2 MODEL Makassar tahun pelajaran 2016/2017 yang jumlah masing-masing siswa terdiri dari 41 siswa dan 40 siswa. Pemilihan siswa kelas X MIA tersebut dengan pertimbangan bahwa siswa tersebut dipastikan telah mempelajari materi sistem persamaan linear tiga variabel (SPLTV) yang akan dijadikan bahan wawancara pada penelitian ini.

Subjek yang diharapkan pada penelitian ini terdiri atas 4 orang. Tetapi selama proses pengumpulan data, subjek berpola asuh orang tua tipe rejecting/neglecting hanya ditemukan satu siswa. Meskipun tidak ditemukan data orang tua tipe rejecting/neglecting, namun untuk subjek tipe rejecting/neglecting tetap dideskripsikan sebagai data penunjang penelitian. sehingga empat subjek yang diperoleh tetap dideskripsikan metakognisinya dalam memecahkan masalah matematika. Subjek penelitian beserta kategori dan pengkodeannya disajikan pada Tabel 1.

Tabel 1. Rincian Subjek Penelitian

\begin{tabular}{ccc}
\hline Inisial Subjek & Kategori & Kode \\
\hline MH & tipe Authoritative & S-AV \\
SK & tipe Autoritarian & S-AR \\
SF & tipe Permissive & S-PM \\
NT & tipe Rejecting-Neglecting & S-RN \\
\hline
\end{tabular}

\section{Instrumen Penelitian}

Instrumen yang digunakan untuk mengumpulkan data pada penelitian ini adalah instrumen utama yaitu peneliti sendiri dan instrumen pendukung yaitu kuesioner pengelompokkan tipe pola asuh orang tua untuk mengkategorikan tipe pola asuh orang tua, tes pemecahan masalah sistem persamaan linear tiga variabel (SPLTV) dan pedoman wawancara untuk mengetahui metakognisi subjek dalam memecahkan masalah sistem persamaan linear tiga variabel (SPLTV).

\section{Prosedur Penelitian}

1. Tahap perencanaan dilakukan dengan mempersiapkan instrumen, melakukan validasi pakar, dan menganalisis dan merevisi hasil validasi.

2. Tahap pelaksanaan dilakukan dengan memberikan kuesioner pengelompokkan tipe pola asuh orang tua kepada calon subjek dan menentukan subjek sesuai tipe, hingga melakukan wawancara kepada orangtua subjek yang terpilih. 
Selanjutnya memberikan tes pemecahan masalah sistem persamaan linear tiga variabel (SPLTV) kepada setiap subjek, hingga melakukan wawancara mengenai tes pemecahan masalah SPLTV.

3. Tahap analisis data dilakukan dengan reduksi data, pemaparan data, dan penarikan kesimpulan. Untuk pemaparan data, pengkodean indikator keterampilan metakognisi subjek yang digunakan dalam memecahkan masalah sistem persamaan linear tiga variabel yang digunakan peneliti dirincikan pada Tabel 2.

Tabel 2. Pengkodean Indikator Keterampilan Metakognisi Siswa Dalam Memecahkan Masalah

\begin{tabular}{|c|c|c|c|c|}
\hline No. & Tahapan Polya & $\begin{array}{c}\text { Keterampilan } \\
\text { Metakognisi }\end{array}$ & Indikator & Kode \\
\hline \multirow[t]{5}{*}{1} & $\begin{array}{l}\text { Memahami } \\
\text { Masalah }\end{array}$ & $\begin{array}{l}\text { Keterampilan } \\
\text { perencanaan }\end{array}$ & $\begin{array}{l}\text { a. Siswa membaca } \\
\text { pernyataan masalah` hingga } \\
\text { paham }\end{array}$ & $1 \mathrm{KPa}$ \\
\hline & & & $\begin{array}{l}\text { b. Siswa dapat } \\
\text { memahami soal dengan } \\
\text { menggunakan kata-kata sendiri }\end{array}$ & $1 \mathrm{KPb}$ \\
\hline & & & $\begin{array}{l}\text { C. Siswa dapat } \\
\text { mengingat masalah yang serupa } \\
\text { dengan masalah yang dihadapi }\end{array}$ & $1 \mathrm{KPC}$ \\
\hline & & & $\begin{array}{l}\text { d. Siswa dapat } \\
\text { menuliskan yang diketahui dan } \\
\text { ditanyakan dari masalah }\end{array}$ & $1 \mathrm{KPd}$ \\
\hline & & $\begin{array}{l}\text { Keterampilan } \\
\text { prediksi }\end{array}$ & $\begin{array}{l}\text { Siswa dapat memprediksikan } \\
\text { hubungan antara masalah yang } \\
\text { diberikan dengan tujuan masalah }\end{array}$ & $1 \mathrm{KPr}$ \\
\hline \multirow[t]{3}{*}{2} & \multirow[t]{3}{*}{ Menyusun masalah } & $\begin{array}{l}\text { Keterampilan } \\
\text { perencanaan }\end{array}$ & $\begin{array}{l}\text { a. Siswa dapat } \\
\text { memperoleh rencana } \\
\text { penyelesaian dari permasalahan }\end{array}$ & $2 \mathrm{KPa}$ \\
\hline & & & $\begin{array}{l}\text { b. Siswa dapat } \\
\text { memilih metode dan langkah- } \\
\text { langkah pemecahan masalah }\end{array}$ & $2 \mathrm{KPb}$ \\
\hline & & $\begin{array}{c}\text { Keterampilan } \\
\text { prediksi }\end{array}$ & $\begin{array}{l}\text { Siswa dapat memprediksi ketepatan } \\
\text { metode dan langkah-langkah yang } \\
\text { akan digunakan untuk menyelesaikan } \\
\text { masalah }\end{array}$ & $2 \mathrm{KPr}$ \\
\hline
\end{tabular}

\section{HASIL PENELITIAN DAN PEMBAHASAN}

\section{Hasil Penelitian}

a. Subjek berpola asuh orang tua tipe authoritative (AV)

Berikut ini paparan mengenai keterkaitan indikator penelitian dengan hasil tes dan wawancara subjek tipe authoritative mengenai tes pemecahan masalah sistem persamaan linear tiga variabel. 
a. Tahap memahami masalah

Tabel 3. Data Metakognisi Subjek Berpola Asuh Orangtua Tipe Authoritative dalam Memecahkankan Masalah SPLTV pada Tahap Memahami Masalah

\begin{tabular}{clc}
\hline Sumber & \multicolumn{1}{c}{$\begin{array}{l}\text { Metakognisi Subjek Berpola Asuh Orangtua Tipe Authoritative dalam } \\
\text { Memecahkan Masalah pada Tahap Memahami Masalah }\end{array}$} & $\begin{array}{c}\text { Kode } \\
\text { Indikator }\end{array}$ \\
\hline Hasil Tes & $\begin{array}{l}\text { Subjek menuliskan unsur - unsur yang diketahui dalam bentuk } \\
\text { persamaan matematika, dan unsur-unsur yang ditanyakan. } \\
\text { Subjek menjumpai masalah SPLTV yang serupa dengan } \\
\text { masalah yang dihadapi pada semester lalu/ganjil }\end{array}$ & $1 \mathrm{KPC}$ \\
Wubjek memprediksikan hubungan penyelesaian yang bisa dilakukan & $1 \mathrm{KPr}$ \\
& $\begin{array}{l}\text { Subjek menceritakan masalah berdasarkan soal dengan menggunakan } \\
\text { kata-kata sendiri. } \\
\text { Subjek mampu memahami masalah setelah membaca soal } \\
\text { lebih dari dua kali. } \\
\text { Subjek memprediksikan hubungan antara masalah yang } \\
\text { dipahami pada soal dengan tahap penyelesaian yang harus } \\
\text { dilakukan sebelum memperoleh hasil akhir soal. }\end{array}$ & $1 \mathrm{KPa}$ \\
\hline
\end{tabular}

b. Tahap menyusun masalah

Tabel 4. Data Metakognisi Subjek Berpola Asuh Orangtua Tipe Authoritative dalam Memecahkankan Masalah SPLTV pada Tahap Menyusun Masalah

\begin{tabular}{clc}
\hline Sumber & \multicolumn{1}{c}{$\begin{array}{c}\text { Metakognisi Subjek Berpola Asuh Orangtua Tipe } \text { Authoritative dalam } \\
\text { Memecahkan Masalah pada Tahap Menyusun Masalah }\end{array}$} & $\begin{array}{c}\text { Kode } \\
\text { Indikator }\end{array}$ \\
\hline Hasil Tes & $\begin{array}{l}\text { Subjek menuliskan metode Cramer dan metode substitusi-eliminasi } \\
\text { sebagai rencana strategi untuk pemecahan masalah SPLTV. }\end{array}$ & $2 \mathrm{KPa}$ \\
Wawancara & $\begin{array}{l}\text { Subjek menuliskan alasan singkat memilih metode tersebut. } \\
\text { Subjek mampu memikirkan rencana pemecahan masalah/metode } \\
\text { menyelesaikan soal tersebut yang lebih mudah. }\end{array}$ & $2 \mathrm{KPb}$ \\
& $\begin{array}{l}\text { Subjek dapat memprediksikan waktu yang dibutuhkan untuk } \\
\text { menyelesaikan masalah tersebut dengan metode yang dipilih }\end{array}$ & $2 \mathrm{KPa}$ \\
\hline
\end{tabular}

c. Tahap melaksanakan rencana

Tabel 5. Data Metakognisi Subjek Berpola Asuh Orangtua Tipe Authoritative dalam Memecahkankan Masalah SPLTV pada Tahap Melaksanakan Rencana

\begin{tabular}{clc}
\hline Sumber & \multicolumn{1}{c}{$\begin{array}{c}\text { Metakognisi Subjek Berpola Asuh Orangtua Tipe Authoritative dalam } \\
\text { Memecahkan Masalah pada Tahap Melaksanakan Rencana }\end{array}$} & $\begin{array}{c}\text { Kode } \\
\text { Indikator }\end{array}$ \\
\hline Hasil Tes & $\begin{array}{l}\text { Subjek menggunakan metode pemecahan berdasarkan metode yang } \\
\text { direncanakan pada tahap menyusun masalah, subjek menuliskan } \\
\text { langkah-langkah metode penyelesaian masalah secara runtut, namun } \\
\text { subjek tidak menuliskan secara lengkap keterangan dan kode angka } \\
\text { persamaan yang disubtitusi ke persamaan yang lain. } \\
\text { Subjek tidak menuliskan satuan harga pada nilai yang diperoleh setiap } \\
\text { variabel untuk menunjukkan harga setiap buah, tetapi tetap } \\
\text { menemukan jawaban akhir soal. }\end{array}$ & 3KMa \\
& 3KMc
\end{tabular}


Wawancara Subjek dapat menjelaskan proses penyelesaian metode pemecahan

masalah (metode eliminasi-substitusi) setelah mengubah permasalahan

ke model matematika yakni, menjelaskan persamaan yang dieliminasi untuk memperoleh persamaan baru sehingga memperoleh nilai setiap variable-variable.

Subjek mampu memperoleh nilai setiap variabel (harga setiap buah)

3KMC dan memperoleh hasil akhir dari tujuan permasalahan (harga buah yang paling mahal), namun subjek tidak menyebutkan secara lengkap nilai satuan.

d. Tahap memeriksa kembali

Tabel 6. Data Metakognisi Subjek Berpola Asuh Orangtua Tipe Authoritative dalam Memecahkankan Masalah SPLTV pada Tahap Memeriksa Kembali

\begin{tabular}{|c|c|c|}
\hline Sumber & $\begin{array}{l}\text { Metakognisi Subjek Berpola Asuh Orangtua Tipe Authoritative dalam } \\
\text { Memecahkan Masalah pada Tahap Memeriksa Kembali }\end{array}$ & $\begin{array}{l}\text { Kode } \\
\text { Indikator }\end{array}$ \\
\hline \multirow[t]{3}{*}{ Hasil Tes } & $\begin{array}{l}\text { Subjek menuliskan contoh pengujian (mensubstitusi variabel } x \text { dan } y \text { ke } \\
\text { persamaan (2). }\end{array}$ & $4 \mathrm{KMb}$ \\
\hline & $\begin{array}{l}\text { Subjek menuliskan kesimpulan atas jawaban yang diperolehnya sudah } \\
\text { benar }\end{array}$ & 4KMc \\
\hline & $\begin{array}{l}\text { Subjek mampu membenarkan kesalahan dari langkah proses } \\
\text { perhitungan yang dilakukan dan menuliskan kembali proses perhitungan } \\
\text { secara tepat }\end{array}$ & 4KEa \\
\hline \multirow[t]{2}{*}{ Wawancara } & $\begin{array}{l}\text { Subjek menjelaskan proses strategi pemecahan yang telah dilakukan } \\
\text { sambil memeriksa kebenaran hasil perhitungan. } \\
\text { Subjek dapat menjelaskan metode pemecahan lain yang bisa }\end{array}$ & $4 \mathrm{KMa}$ \\
\hline & memecahkan permasalahan. & 4KEb \\
\hline
\end{tabular}

\section{Subjek berpola asuh orang tua tipe authoritarian (AR)}

Berikut ini paparan mengenai keterkaitan indikator penelitian dan wawancara subjek tipe authoritarian mengenai tes pemecahan masalah sistem persamaan linear tiga variabel.

a. Tahap memahami masalah

Tabel 7. Data Metakognisi Subjek Berpola Asuh Orangtua Tipe Authoritarian dalam Memecahkankan Masalah SPLTV pada Tahap Memahami Masalah

dengan hasil tes

\begin{tabular}{clc}
\hline Sumber & \multicolumn{1}{c}{$\begin{array}{c}\text { Metakognisi Subjek Berpola Asuh Orangtua Tipe Authoritarian dalam } \\
\text { Memecahkan Masalah pada Tahap Memahami Masalah }\end{array}$} & $\begin{array}{c}\text { Kode } \\
\text { Indikator }\end{array}$ \\
\hline Hasil Tes & $\begin{array}{l}\text { Subjek menuliskan unsur - unsur yang diketahui serta menuliskan } \\
\text { persamaan matematika berdasarkan unsur yang diketahui. } \\
\text { Subjek dapat menceritakan masalah, yakni menjelaskan permasalahan } \\
\text { yang akan ditentukan pada soal dengan kata-kata sendiri } \\
\text { Subjek mampu memahami masalah setelah membaca soal } \\
\text { lebih dari dua kali. } \\
\begin{array}{l}\text { Subjek pernah mempelajari menyelesaikan soal yang serupa dengan } \\
\text { soal yang dihadapi }\end{array}\end{array}$ & $1 \mathrm{KPb}$ \\
\hline
\end{tabular}


Subjek memprediksikan hubungan antara masalah yang $1 \mathrm{KPr}$ dipahami pada soal dengan unsur-unsur yang harus ditentukan.

b. Tahap menyusun masalah

Tabel 8. Data Metakognisi Subjek Berpola Asuh Orangtua Tipe Authoritarian dalam Memecahkankan Masalah SPLTV pada Tahap Menyusun Masalah

\begin{tabular}{clc}
\hline \multicolumn{1}{c}{ Sumber } & \multicolumn{1}{c}{$\begin{array}{c}\text { Metakognisi Subjek Berpola Asuh Orangtua Tipe } \text { Authoritarian dalam } \\
\text { Memecahkan Masalah pada Tahap Menyusun Masalah }\end{array}$} & $\begin{array}{c}\text { Kode } \\
\text { Indikator }\end{array}$ \\
\hline Hasil Tes & $\begin{array}{l}\text { Subjek menuliskan metode substitusi-eliminasi sebagai rencana strategi } \\
\text { untuk pemecahan masalah sistem persamaan linear tiga variabel. }\end{array}$ & $2 \mathrm{KPa}$ \\
Wawancara & $\begin{array}{l}\text { Subjek menuliskan alasan singkat memilih metode tersebut. } \\
\text { Subjek memprediksi ketepatan metode yang dipilih dan waktu yang } \\
\text { dibutuhkan (45 menit) dalam menggunakan metode yang dipilih untuk } \\
\text { menyelesaikan masalah. }\end{array}$ & $2 \mathrm{KPb}$ \\
& & $2 \mathrm{KPr}$ \\
\hline
\end{tabular}

c. Tahap melaksanakan rencana

Tabel 9. Data Metakognisi Subjek Berpola Asuh Orangtua Tipe Authoritarian dalam Memecahkankan Masalah SPLTV pada Tahap Melaksanakan Rencana

\begin{tabular}{clc}
\hline Sumber & \multicolumn{1}{c}{$\begin{array}{c}\text { Metakognisi Subjek Berpola Asuh Orangtua Tipe } \text { Authoritarian dalam } \\
\text { Memecahkan Masalah pada Tahap Melaksanakan Rencana }\end{array}$} & $\begin{array}{c}\text { Kode } \\
\text { Indikator }\end{array}$ \\
\hline Hasil Tes & $\begin{array}{l}\text { Subjek menuliskan langkah-langkah metode penyelesaian masalah } \\
\text { secara runtut, serta menuliskan secara lengkap keterangan dan kode } \\
\text { angka persamaan yang dieliminasi dan nilai yang disubstitusi ke } \\
\text { persamaan. }\end{array}$ & 3KMa \\
Wawancara & $\begin{array}{l}\text { Subjek mampu menemukan jawaban akhir dari soal. } \\
\text { Subjek dapat menjelaskan proses penyelesaian metode pemecahan } \\
\text { masalah (metode eliminasi-substitusi) setelah mengubah permasalahan } \\
\text { ke model matematika yakni, menjelaskan persamaan yang dieliminasi } \\
\text { untuk memperoleh persamaan baru sehingga memperoleh nilai setiap } \\
\text { variable-variable. }\end{array}$ & 3KMc \\
\hline
\end{tabular}

d. Tahap memeriksa kembali

Tabel 10. Data Metakognisi Subjek Berpola Asuh Orangtua Tipe Authoritarian dalam Memecahkankan Masalah SPLTV pada Tahap Memeriksa Kembali

\begin{tabular}{llc}
\hline \multicolumn{1}{c}{ Sumber } & \multicolumn{1}{c}{$\begin{array}{c}\text { Metakognisi Subjek Berpola Asuh Orangtua Tipe Authoritarian dalam } \\
\text { Memecahkan Masalah pada Tahap Memeriksa Kembali }\end{array}$} & $\begin{array}{c}\text { Kode } \\
\text { Indikator }\end{array}$ \\
\hline Hasil Tes & $\begin{array}{l}\text { Subjek menuliskan alasan bahwa yakin atas jawaban yang diperoleh. } \\
\text { Wawancara }\end{array}$ & $\begin{array}{l}\text { Subjek beberapa kali memeriksa proses penyelesaian pemecahan } \\
\text { masalah yang dilakukan dan hasil perhitungan. }\end{array}$ \\
& $\begin{array}{l}\text { Subjek menjelaskan kebenaran atas jawaban yang sudah ada dengan } \\
\text { maksud soal. }\end{array}$ & 4KMa \\
\hline
\end{tabular}

\section{Subjek berpola asuh orang tua tipe permissive (PM)}

Berikut ini paparan mengenai keterkaitan indikator penelitian dengan hasil tes dan wawancara subjek tipe permissive mengenai tes pemecahan masalah sistem persamaan linear tiga variabel. 
a. Tahap memahami masalah

Tabel 11. Data Metakognisi Subjek Berpola Asuh Orangtua Tipe Permissive dalam Memecahkankan Masalah SPLTV pada Tahap Memahami Masalah

\begin{tabular}{clc}
\hline Sumber & \multicolumn{1}{c}{$\begin{array}{c}\text { Metakognisi Subjek Berpola Asuh Orangtua Tipe Permissive dalam } \\
\text { Memecahkan Masalah pada Tahap Memahami Masalah }\end{array}$} & $\begin{array}{c}\text { Kode } \\
\text { Indikator }\end{array}$ \\
\hline Hasil Tes & $\begin{array}{l}\text { Subjek dapat menuliskan pemisalan dan memodelkan persamaan } \\
\text { matematika sebagai unsur-unsur yang diketahui dari masalah. } \\
\text { Subjek menuliskan unsur yang ditanyakan dari masalah. } \\
\text { Wawancara }\end{array}$ & $\begin{array}{l}\text { Subjek menggunakan kemampuan visual (membaca) untuk } \\
\text { memperoleh gambaran penyelesaian. }\end{array}$ \\
$\begin{array}{l}\text { Subjek mengingat pada saat mempelajari materi dan masalah } \\
\text { sebelumnya yang serupa dengan masalah yang dihadapi. } \\
\text { Subjek hanya menjelaskan inti unsur yang ditanyakan pada soal } \\
\text { Subjek berusaha memahami masalah dengan baik, subjek dapat } \\
\text { menceritakan hal yang diprediksi untuk dilakukan dalam memecahkan } \\
\text { permasalahan pada soal dengan menggunakan kata-kata sendiri. }\end{array}$ & $1 \mathrm{KPa}$ \\
\hline
\end{tabular}

b. Tahap menyusun masalah

Tabel 12. Data Metakognisi Subjek Berpola Asuh Orangtua Tipe Permissive dalam Memecahkankan Masalah SPLTV pada Tahap Menyusun Masalah

\begin{tabular}{clc}
\hline Sumber & \multicolumn{1}{c}{$\begin{array}{c}\text { Metakognisi Subjek Berpola Asuh Orangtua Tipe Permissive dalam } \\
\text { Memecahkan Masalah pada Tahap Menyusun Masalah }\end{array}$} & $\begin{array}{c}\text { Kode } \\
\text { Indikator }\end{array}$ \\
\hline Hasil Tes & $\begin{array}{l}\text { Subjek menuliskan metode substitusi-eliminasi sebagai rencana strategi } \\
\text { untuk pemecahan masalah sistem persamaan linear tiga variabel. }\end{array}$ & $2 \mathrm{KPa}$ \\
& $\begin{array}{l}\text { Subjek mampu menjelaskan rencana langkah pemecahan masalah } \\
\left(\mathrm{PM} \mathrm{M}_{19}\right) \text { yang dipilh, yakni metode substitusi. } \\
\text { Subjek menjelaskan alasan bahwa metode yang akan digunakan dapat } \\
\text { menyelesaikan masalah, serta keterkaitan hubungan masalah dengan } \\
\text { tujuan dari permasalahan yang akan diperoleh. }\end{array}$ & $2 \mathrm{KPb}$ \\
\hline
\end{tabular}

\section{Tahap melaksanakan rencana}

Tabel 13. Data Metakognisi Subjek Berpola Asuh Orangtua Tipe Permissive dalam Memecahkankan Masalah SPLTV pada Tahap Melaksanakan Rencana

\begin{tabular}{clc}
\hline Sumber & \multicolumn{1}{c}{$\begin{array}{c}\text { Metakognisi Subjek Berpola Asuh Orangtua Tipe Permissive dalam } \\
\text { Memecahkan Masalah pada Tahap Melaksanakan Rencana }\end{array}$} & $\begin{array}{c}\text { Kode } \\
\text { Indikator }\end{array}$ \\
\hline Hasil Tes & $\begin{array}{l}\text { Subjek menuliskan langkah-langkah metode penyelesaian masalah } \\
\text { secara runtut, namun tidak menuliskan secara urut mulai dari kode } \\
\text { angka persamaan dari unsur-unsur yang diketahui }\end{array}$ & 3KMa \\
& $\begin{array}{l}\text { Subjek dapat menjelaskan proses penyelesaian metode pemecahan } \\
\text { masalah (metode substitusi) setelah mengubah permasalahan ke model } \\
\text { matematika yakni, memilih persamaan yang diketahui untuk diubah } \\
\text { menjadi persamaan baru sehingga bisa disubstitusikan ke persamaan } \\
\text { yang sesuai. } \\
\begin{array}{l}\text { Subjek mampu memperoleh nilai setiap variabel (harga setiap buah) } \\
\text { dan memperoleh hasil akhir dari tujuan permasalahan (harga buah yang }\end{array}\end{array}$ & 3KMb \\
\hline
\end{tabular}


paling mahal), namun subjek tidak menyebutkan secara lengkap satuannya.

d. Tahap memeriksa kembali

Tabel 14. Data Metakognisi Subjek Berpola Asuh Orangtua Tipe Permissive dalam Memecahkankan Masalah SPLTV pada Tahap Memeriksa Kembali

\begin{tabular}{clc}
\hline Sumber & $\begin{array}{c}\text { Metakognisi Subjek Berpola Asuh Orangtua Tipe Permissive dalam } \\
\text { Memecahkan Masalah pada Tahap Memeriksa Kembali }\end{array}$ & $\begin{array}{c}\text { Kode } \\
\text { Indikator }\end{array}$ \\
\hline Hasil Tes & $\begin{array}{l}\text { Subjek menuliskan alasan bahwa yakin atas jawaban yang diperoleh. } \\
\text { Subjek menuliskan bahwa masih ada metode yang berbeda dari metode } \\
\text { yang sebelumnya digunakan, namun subjek tidak dapat melakukan } \\
\text { metode tersebut. }\end{array}$ & $\begin{array}{c}\text { 4KMc } \\
\text { 4KEb }\end{array}$ \\
\hline
\end{tabular}

\section{Subjek berpola asuh orang tua tipe rejecting/neglecting (RN)}

Berikut ini paparan mengenai keterkaitan indikator penelitian dengan hasil tes dan wawancara subjek tipe rejecting/neglecting mengenai tes pemecahan masalah sistem persamaan linear tiga variabel.

a. Tahap memahami masalah

Tabel 15. Data Metakognisi Subjek Berpola Asuh Orangtua Tipe Rejecting/neglecting dalam Memecahkankan Masalah SPLTV pada Tahap Memahami Masalah

\begin{tabular}{cllc}
\hline Sumber & \multicolumn{1}{c}{$\begin{array}{c}\text { Metakognisi Subjek Berpola Asuh Orangtua Tipe Rejecting/neglecting } \\
\text { dalam Memecahkan Masalah pada Tahap Memahami Masalah }\end{array}$} & $\begin{array}{c}\text { Kode } \\
\text { Indikator }\end{array}$ \\
\hline Hasil Tes & $\begin{array}{l}\text { Subjek menuliskan unsur-unsur yang diketahui dan unsur-unsur yang } \\
\text { ditanyakan. }\end{array}$ & $1 \mathrm{KPd}$ \\
& $\begin{array}{l}\text { Subjek menyatakan memahami masalah setelah beberapa kali } \\
\text { membaca soal. } \\
\text { Subjek pernah mempelajari materi yang membahas masalah Sistem } \\
\text { persamaan linear tiga variabel yang serupa dengan masalah yang } \\
\text { dihadapi. } \\
\text { Subjek dapat memprediksi hubungan antara masalah pada soal dengan } \\
\text { inti pertanyaan atau tujuan masalah. }\end{array}$ & $1 \mathrm{KPa}$ \\
\hline
\end{tabular}

b. Tahap menyusun masalah

Tabel 16. Data Metakognisi Subjek Berpola Asuh Orangtua Tipe Rejecting/neglecting dalam Memecahkankan Masalah SPLTV pada Tahap Menyusun Masalah

\begin{tabular}{clcc}
\hline Sumber & \multicolumn{1}{c}{$\begin{array}{c}\text { Metakognisi Subjek Berpola Asuh Orangtua Tipe Rejecting/neglecting } \\
\text { dalam Memecahkan Masalah pada Tahap Menyusun Masalah }\end{array}$} & $\begin{array}{c}\text { Kode } \\
\text { Indikator }\end{array}$ \\
\hline Hasil Tes & $\begin{array}{l}\text { Subjek memikirkan rencana penyelesaian masalah yang lebih mudah } \\
\text { dan sesuai dengan materi penyelesaian masalah system persamaan } \\
\text { linear tiga variable yang telah dipelajari. }\end{array}$ & $2 \mathrm{KPa}$ \\
& $\begin{array}{l}\text { Subjek memilih metode Gramer dan eliminasi untuk menyelesaikan } \\
\text { permasalahan. } \\
\text { Subjek memprediksi bahwa metode Gramer dan eliminasi akan dapat } \\
\text { menyelesaikan permasalahan, karena telah mempelajari metode }\end{array}$ & $2 \mathrm{KPb}$ \\
\hline
\end{tabular}


Gramer dan eliminasi.

C. Tahap melaksanakan rencana

Tabel 17. Data Metakognisi Subjek Berpola Asuh Orangtua Tipe Rejecting/neglecting dalam Memecahkankan Masalah SPLTV pada Tahap Melaksanakan Rencana

\begin{tabular}{llc}
\hline \multicolumn{1}{c}{ Sumber } & $\begin{array}{c}\text { Metakognisi Subjek Berpola Asuh Orangtua Tipe Rejecting/neglecting } \\
\text { dalam Memecahkan Masalah pada Tahap Melaksanakan Rencana }\end{array}$ & $\begin{array}{c}\text { Kode } \\
\text { Indikator }\end{array}$ \\
\hline Hasil Tes & $\begin{array}{l}\text { Subjek hanya menuliskan satu langkah metode eliminasi saja } \\
\text { Wawancara }\end{array}$ & $\begin{array}{l}\text { Subjek mengalami kesulitan menjelaskan tahapan dan proses } \\
\text { menyelesaikan masalah mulai awal hingga akhir }\end{array}$ \\
\hline
\end{tabular}

\section{d. Tahap memeriksa kembali}

Data metakognisi subjek berpola asuh orangtua tipe rejecting/neglecting dalam memecahkan masalah SPLTV menunjukkan bahwa pada tahap memeriksa kembali Subjek hanya menuliskan bahwa tidak ada metode lain yang berbeda dari metode yang sebelumnya direncanakan, namun subjek tidak berhasil menyelesaikan metode yang telah direncanakan. Sedangkan pada data wawancara, subjek tidak dapat menjelaskan langkah-langkah penyelesaian masalah yang direncanakan, karena subjek tidak dapat mengingat pengetahuan yang telah dipelajari sebelumnya.

\section{Pembahasan}

1. Subjek berpola asuh orang tua tipe authoritative (AV)

Berdasarkan data pada bagian hasil, diperoleh bahwa data metakognisi subjek berpola asuh orang tua tipe authoritative (AV) dalam pemecahan masalah matematika pada tahap memahami masalah, menyusun masalah, melaksanakan rencana, dan memeriksa kembali cenderung konsisten dan dapat dikatakan valid.

Kemampuan subjek dalam melibatkan keterampilan metakognisi terkait dengan pola pengasuhan orangtua tipe authoritative yang dialami subjek. Menurut Baumrind (dalam Agustiawati, 2014: 30) menjelaskan karakter siswa mengenai pola asuh orang tua tipe demokratis bahwa anak dalam keluarga yang bersifat demokratis akan mempunyai tanggung jawab yang besar terutama dalam menyelesaikan tugas-tugas pelajaran di sekolah, mampu berinisiatif dan kreatif serta mempunyai konsep diri yang positif. Sikap tanggung jawab yang dimiliki subjek, terlihat dari wawancara subjek menyatakan bahwa metode yang ke dua yang direncanakan dapat pula menyelesaikan masalah. Sehingga subjek berusaha bertanggung jawab untuk membuktikan dengan cara menyelesaiakan kembali metode ke dua tersebut. Meskipun awalnya subjek mengalami kesalahan perhitungan tetapi berusaha kembali memperbaiki proses penyelesaian metode dan perhitungan tersebut hingga memperoleh jawaban yang tepat dan sesuai dengan jawaban pada penyelesaian metode pertama. Selain itu, pada hasil tes 
subjek tipe authoritative lebih punya inisiatif untuk dapat memecahkan masalah dengan menggunakan beberapa metode. Berdasarkan hasil tes, subjek tipe authoritative terbukti dapat memecahkan masalah dengan menggunakan dua metode.

\section{Subjek berpola asuh orang tua tipe authoritarian (AR)}

Berdasarkan data pada bagian hasil, diperoleh bahwa data metakognisi subjek berpola asuh orang tua tipe authoritarian (AR) dalam pemecahan masalah matematika pada tahap memahami masalah, menyusun masalah, melaksanakan rencana, dan memeriksa kembali cenderung konsisten dan dapat dikatakan valid.

Seorang tipe Authoritarian tidak bisa membuat inisiatif untuk berkreativitas dan memiliki kemampuan sosial yang rendah serta kurang percaya diri (Zarbakhsh, Hassanzadeh, Abolghasemi, Dinani, 2012: 10007, 10010). Terkait mengenai seorang tipe Authoritarian tidak bisa membuat inisiatif untuk berkreativitas terukur pada lembar tes subjek yang menginstruksikan "apabila masih ada metode lain yang lebih mudah untuk penyelesaian masalah SPLTV, bagaimana langkah penyelesaian metode tersebut", dalam hal itu subjek menyadari bahwa masih ada metode lain yang bisa menyelesaikan masalah, tetapi subjek tidak berinisiatif untuk memberikan gambaran penyelesaian metode itu. Selain itu pada saat wawancara, subjek menunjukkan sikap yang kurang percaya diri dan kurang tanggapan (responsive). subjek kerap kali menunjukkan sikap yang diam ataupun hanya mengangguk dan kurang merespon. Subjek tidak memberikan penegasan kembali atas penjelasannya, apabila hal yang disampaikannya memang benar adanya. Dalam hal ini berdasarkan pada penunjukan Maccoby \& Martin (Baumrind, 1991) bahwa pola asuh authoritarian memiliki tingkat tuntutan (demandingness) yang tinggi akan tetapi rendah tanggapan (responsiveness).

3. Subjek berpola asuh orang tua tipe permissive (PM)

Berdasarkan data pada bagian hasil, diperoleh bahwa data metakognisi subjek berpola asuh orang tua tipe permissive (PM) dalam pemecahan masalah matematika pada tahap memahami masalah, menyusun masalah, melaksanakan rencana, dan memeriksa kembali cenderung konsisten dan dapat dikatakan valid.

Subjek tipe permissive hanya melaksanakan rencana pemecahan masalah yang menurutnya telah selesai, tetapi tidak memikirkan bahwa hal yang telah dilakukan kemungkinan masih ada yang perlu diperbaiki. Subjek tipe permissive kurang memiliki kontrol diri. Dalam hal ini subjek tidak melibatkan metakognisinya yakni keterampilan monitoring. Kurangnya kontrol diri pada setiap anak bisa disebabkan oleh pengasuhan yang cenderung memanjakan dan memberikan pembebasan lebih pada anak. Menurut Bety (2012: 170), cara dalam pola asuh yang dilakukan oleh orangtua pada tipe permissive memiliki kehangatan, akan tetapi kehangatannya cenderung memanjakan. Orang tua beranggapan bahwa anak akan belajar dari kesalahannya. Berdasarkan yang dilakukan subjek dalam hal ini menunjukkan bahwa subjek tidak terbiasa menegur diri sendiri untuk memeriksa kembali apa yang telah dilakukan. 
4. Subjek berpola asuh orang tua tipe rejecting/neglecting (RN)

Berdasarkan data pada bagian hasil, diperoleh data metakognisi subjek berpola asuh orang tua tipe rejecting/neglecting $(\mathrm{RN})$ dalam pemecahan masalah matematika hanya pada tahap memahami masalah, dan menyusun masalah.

Subjek tidak mampu mencapai tahap melaksanakan rencana dan tahap memeriksa kembali, sehingga keterampilan metakognisi yang bisa dilibatkan pada kedua tahap tersebut tidak terukur. Subjek tidak dapat melibatkan keterampilan monitoring karena ketidakmampuannya mencapai tahap melaksanakan rencana. Hal ini sangat memungkinkan mengingat subjek yang memiliki pola asuh tipe rejecting/neglecting yang cenderung memiliki karakteristik kurang bertanggung jawab dan masalah dengan pengendalian diri. Menurut Baumrind (1991: 56) ciriciri orang tua yang tergolong tipe rejecting/neglecting salah satunya, tidak membimbing dan memantau anak-anak mereka. Sehingga berakibat subjek pada tipe rejecting/neglecting cenderung kurang bertanggung jawab dan masalah dengan pengendalian diri.

\section{SIMPULAN DAN SARAN \\ Simpulan}

Kesimpulan dari hasil penelitian ini adalah sebagai berikut:

1. Deskripsi metakognisi subjek berpola asuh orang tua tipe authoritative (AV) dalam pemecahan masalah SPLDV, yang terdiri dari (1) tahap memahami masalah melibatkan keterampilan dan keterampilan prediksi; (2) tahap menyusun masalah, melibatkan keterampilan perencanaan dan keterampilan prediksi; (3) tahap melaksanakan rencana, melibatkan keterampilan monitoring ; (4) tahap memeriksa kembali, melibatkan keterampilan monitoring dan keterampilan evaluasi.

2. Deskripsi metakognisi subjek berpola asuh orang tua tipe authoritarian (AR) dalam pemecahan masalah SPLDV, yang terdiri dari (1) tahap memahami masalah melibatkan keterampilan dan keterampilan prediksi; (2) tahap menyusun masalah, melibatkan keterampilan perencanaan dan keterampilan prediksi; (3) tahap melaksanakan rencana, melibatkan keterampilan monitoring ; (4) tahap memeriksa kembali, melibatkan keterampilan monitoring.

3. Deskripsi metakognisi subjek berpola asuh orang tua tipe permissive (PM) dalam pemecahan masalah SPLDV, yang terdiri dari (1) tahap memahami masalah melibatkan keterampilan dan keterampilan prediksi; (2) tahap menyusun masalah, melibatkan keterampilan perencanaan dan keterampilan prediksi; (3) tahap melaksanakan rencana, melibatkan keterampilan monitoring ; (4) tahap memeriksa kembali, melibatkan keterampilan monitoring.

4. Deskripsi metakognisi subjek berpola asuh orang tua tipe permissive (PM) dalam pemecahan masalah SPLDV, yang terdiri dari (1) tahap memahami masalah melibatkan keterampilan dan keterampilan prediksi; (2) tahap menyusun masalah, melibatkan keterampilan perencanaan dan keterampilan prediksi. 


\section{Saran} dilakukan

Adapun saran dari peneliti sehubungan dengan penelitian yang telah adalah sebagai berikut:

1. Peneliti hanya mengungkap keterlibatan keterampilan metakognisi siswa dalam memecahkan masalah matematika ditinjau dari pola asuh orangtua sehingga untuk penelitian selanjutnya diharapkan agar dapat mengungkap keterlibatan metakognisi siswa dalam proses belajar, dan tentunya lebih baik apabila ditambah dengan ditinjau dari metode mengajar guru.

2. Terkait kelemahan penelitian yang ditemukan sebelumnya yang telah dikemukakan di BAB IV, peneliti menyarankan agar penelitian selanjutnya yang terkait dengan penelitian ini dapat meminimalisir kelemahan-kelemahan tersebut.

\section{DAFTAR PUSTAKA}

Agustiawati, Isni. 2014. Pengaruh Pola Asuh Orangtua terhadap Prestasi Siswa pada Mata Pelajaran Akuntansi Kelas XI IPS di SMA Negeri 26 Bandung. Universitas Pendidikan Indonesia: Repository. Upi. Edu.

Anggo, Mustamin. Salam, Moammad. Suhar \& Yulsi, Sanri. Strategi Metakognisi untuk Meningkatkan Hasil Belajar Matematika Siswa. Jurnal Pendidikan matematika. Vol. 5 No. 1. PMIPA FKIP UHO.

Arsyad, Nurdin. 2016. Model Pembelajaran Menumbuhkembangkan Kemampuan Metakognitif. Makassar: Pustaka Refleksi.

Baumrind, D. 1991. The Influence of Parenting Style on Adolescent Competence and Subtance Use. Journal of Early Adolescent, 11(1), 56-95.

Beck, Joan. 1992. Asih, Asah, Asuh, Mengasuh dan Mendidik Anak agar Cerdas. Semarang: Dahara Prize.

Bety, Bea Septiari. 2012. Mencetak Balita Cerdas dan Pola Asuh Orang Tua. Yogyakarta. Nuha Medika.

Desmita. 2011. Psikologi Perkembangan Peserta Didik. Bandung: PT Remaja Rosda Karya.

Desoete, Annemie. 2008. Multi-method assessment of metacognitive skills in elementary school children: how you test is what you get. Metacognition Learning. Department of experimental clinical and health psychology, Ghent University.

Rita, Eka I., Partini S, Siti., Yulia A., Purwandari, Hiryanto \& Rosita, E. 2008. Perkembangan Peserta Didik. Yogyakarta: UNY Press.

Suherman, Erman dkk. 2003. Strategi Pembelajaran Matematika Kontemporer. Bandung: JICA; Universitas Pendidikan Indonesia.

Zarbakhsh, M., Hassanzadeh, S., Abolghasemi, S., Dinani, P. T. 2012. Relationship between Perceived Parenting Styles and Critical Thinking with Cognitive Learning Styles. Journal of Basic and Applied Scientific Research. Vol. 2(10): 10007-10011 